\title{
Challenges for brownfield regeneration: a comparison of English and Japanese approaches
}

\author{
N. Otsuka ${ }^{1} \& \mathrm{H}$. Abe \\ ${ }^{1}$ Department of Real Estate and Construction, \\ School of the Built Environment, Oxford Brookes University, UK \\ ${ }^{2}$ Department of Global Architecture, Graduate School of Engineering, \\ Osaka University, Japan
}

\begin{abstract}
This paper explores comparative implications for brownfield regeneration in Japan and England. Concern for brownfield regeneration in Japan has been developed with a strong emphasis on averting environmental risks from contaminated land, rather than on seeking beneficial reuse of brownfield. In contrast, the UK government strategically worked on mitigating such negative views on brownfields and UK urban policies have acted as a key driver for promoting brownfield as a development opportunity. The paper seeks to reveal the contextual differences in the ways of understanding the term 'brownfield' between Japan and England. Historically the Japanese government has a tendency to consult the UK government's planning policies for the purpose of establishing new policy frameworks for emerging urban issues. Thus, the key question to be addressed through this paper is to what extent the English approach is adaptable to the Japanese context.
\end{abstract}

Keywords: brownfield regeneration, urban policy, UK-Japan comparison.

\section{Introduction}

In the rapid movement towards deindustrialisation in Japan since the 1990s, the regeneration of the post-industrial brownfields has been gradually recognised as a key agenda by policy makers, developers and researchers. The term 'brownfield' has started to be used in Japan by referring to relevant research papers and government policy documents in countries such as the UK and the 
USA, which have longer experience in tackling brownfield sites. However, researchers who introduced the study of brownfield regeneration in the UK and the USA [1,2] reported rather descriptive case evidence from these countries without a clarification of contextual differences between Japan and those countries. For the purpose of establishing new policy frameworks for emerging urban issues, few research papers have discussed extensively the contextual differences and commonalities between urban issues in Japan and the UK.

This paper explores comparative implications for brownfield regeneration in Japan and England. The key question to be addressed through this paper is to what extent the English approach is adaptable to the Japanese context. There appeared to be fundamental differences in the government policies and public perception regarding brownfield between the two countries. Concern for brownfield regeneration in Japan has been developed with a strong emphasis on averting environmental risks from contaminated land. The Japanese approach assumes a close link between brownfield and contamination, and hence results in conveying negative implication for the management of brownfield sites. In contrast, the UK government worked strategically on mitigating such negative views on brownfields, and UK urban policies have acted as a key driver for branding 'brownfield' as a development opportunity rather than as planning problems [3]. The UK's positive approach towards brownfield regeneration has been further fostered by a relatively buoyant property market and the growing demand for new houses, especially in southern England [4].

The rest of the paper identifies firstly definitions of brownfield in the two countries and then explains the evolution of government strategies and policies on brownfield agendas. Subsequently, key drivers and barriers for promoting brownfield regeneration are compared. The final section concludes and discusses future research issues.

\section{Definition of 'brownfield'}

In England, it is widely recognised that not all brownfield is contaminated. According to Alker et al [5], the term 'brownfield' emerged rather as the opposite of 'greenfield'. However, it was a fact that brownfield historically conveyed negative connotations and was often used interchangeably with the term 'contaminated land'. 'Contaminated land' is defined by the UK Environmental Protection Act 1990 (Section 78Q (2) of Part II A), which was primarily concerned with health risks and thus with identifying any land considered to be in conditions where: (a) significant harm is being caused or there is a significant possibility of such harm being caused; or (b) pollution of controlled waters is being, or is likely to be, caused. While the 'contaminated land' was clearly defined for the purpose of regulating contamination and averting environmental risks through land remediation, there was a lack of a universally agreed or accepted definition of brownfield during the 1990s. This resulted in producing different interpretations of brownfield among not only various stakeholders, but also in government legislative documents, which led to misunderstanding and confusion [5]. 
Therefore it was extremely important for the UK government to stimulate brownfield development in the process of changing negative perceptions, rather than just tackling specific technical land contamination problems [6]. Over the last decade academics as well as government policy makers have debated the definition of brownfield; it is now recognised as land or premises which have been previously developed, whether contaminated or not [7]. The UK government has now defined brownfield as previously developed land (PDL), 'which is or was occupied by a permanent structure, including the curtilage of the developed land and any associated fixed surface infrastructure' [8]. PDL has become the basis for the statistics collected for the NLUD (National Land Use Database), which was launched in 1998 to make assessment of important redevelopment opportunities for such land, particularly residential development potential [3]. In 2005, some 63,490 hectares of land in England were categorised as brownfield land, and it should be emphasised that the fact of contamination was not represented in this data. As Adams and De Sousa [3] maintained, UK policy emphasis was placed not on the reasons why land became vacant or derelict, but rather on the processes by which it might be put to beneficial uses.

In contrast, the concept of brownfield in Japan seems to have mostly evolved with a strong emphasis on identifying the causes for it being vacant or derelict, in other words, risk aversion has been the main concern. Unlike in England, brownfield is a relatively new concept among urban issues in Japan, which has been gradually brought to the fore since the introduction of the Soil Contamination Countermeasures Act 2003 (SCCA). The Act was the first legislation to provide a set of indicators to measure soil contamination for the purpose of preventing adverse effects on public health, and was largely drawn from the USA's approach to contaminated land. Consequently, the focus was placed on ways of tackling the soil contamination rather than on proposing beneficial uses on brownfield sites. A recent publication by Japan's Ministry of the Environment (MoE) uses the definition of brownfield as 'lands which are unused or with extremely limited use compared to their intrinsic value because of existence or potential existence of soil contamination' [9]. The report stated that a small number of lands had been turned into brownfield in Japan since the history of applying soil contamination countermeasures was relatively short [9]. According to Yasutaka [10], only 1 or 2 per cent of potentially contaminated sites had been investigated under the SCCA. However, the actual existence of such land was predicted to be substantially high, and the study carried out by MoE estimated that about 113,000 hectares of land assets had soil contamination, thus having the potential to turn into brownfield [9].

MoE's main concern was the negative effects caused by the increasing number of land investigations of potentially contaminated land under the SCCA [9]. Once land is revealed as brownfield, whether the land appears to be contaminated or not, the revelation has a negative influence on land sales and impedes appropriate management for future use. Furthermore, the process of 'turning into brownfield' inevitably forces stakeholders to confront hostile and unfamiliar environmental issues $[9,10]$. Under such negative implications associated with brownfield, there seems to be not much room for promoting 
brownfield as an opportunity area for future redevelopment in the Japanese context. It has become clear that the ideas of brownfield in Japan and England are considerably different.

\section{Government strategies and policy frameworks}

There are a number of economic, environmental and social barriers intrinsic to brownfield, which would hinder the process of transforming brownfield to beneficial uses. Without government intervention, it seems likely that brownfield sites would not be competitive compared with greenfield [11]. This section starts by explaining the UK government's strategies for promoting brownfield regeneration. Then the current state of the Japanese government's approach to brownfield is discussed.

It can be said that the UK government strategically placed brownfield regeneration as a key delivery mechanism for a new urban renaissance. Since the New Labour government came to power in 1997, urban renaissance has been promoted as the core concept for disseminating the government's commitment to the revitalisation of British cities [12]. Like many other developed countries, the de-industrialisation of the $1980 \mathrm{~s}$ and 1990s forced many cities to rapidly restructure their economic bases from heavy industry to the emerging, nonmanufacturing, knowledge and service based sectors [13]. As a part of the government's response to this, the Urban Task Force (UTF) was established in the late 1990s to propose strategies for the regeneration of such post-industrial sites. The UTF recommended a fundamental urban renaissance in order to attract people back to urban centres through the promotion of urban living and working [14]. Subsequently, the UK government published planning guidance to local authorities, the Planning Policy Statement 1: Delivering Sustainable Development [15], which sets out core principles for the planning system to bring vacant and underused previously developed land and buildings back into beneficial uses [6]. Thus brownfield was promoted as an ideal platform on which to create sustainable environment and communities. For the regeneration of brownfield, the government encouraged adaptation of certain ideas of sustainable urban forms such as high density, mixed-use development, good urban design, and energy efficient buildings and infrastructure [16]. Along with the regeneration of sustainable urban fabrics, it was argued that brownfield-led regeneration would be effective in bringing a range of socio-economic groups together into the newly revitalised urban sites. [17].

The UK government's approach to brownfield regeneration has been further reinforced by recent housing policies. Considering the high demand for new houses in the UK, it is not surprising that there appeared to be a strong linkage in policy terms with the emphasis on brownfield regeneration and the need for new housing on such sites [18]. It was 1998 when the government firstly announced that $60 \%$ of new housing should be provided on PDL and through the conversion of existing buildings by 2008 [19]. A team from the Department of Communities and Local Government (DCLG) and English Partnerships prepared a discussion paper [20] to address the key policy issues and the rationale for 
prioritising the reuse of brownfield lands. Furthermore, the recent Housing Green Paper [21] re-emphasised plans for delivering a large number of new homes ( 2 million new homes by 2016 and 3 million new homes by 2020). According to ODPM's provisional estimate in $2006,73 \%$ of new dwellings were built on PDL (including conversions) in 2005, compared with 56\% in 1993 [19]. In England, negative implications of brownfield seem to have been largely diminished and the presence or potential existence of contamination in such sites has been treated as a secondary issue.

In comparison to the UK, Japan seems to be far behind in establishing government strategies and policies on the regeneration of brownfield sites. The Japanese government's approach to the revitalisation of urban areas officially started with the establishment of the Urban Renaissance Headquarters in 2001, which was led by the then Prime Minister, Mr. Koizumi. The Urban Renaissance Special Measure Law was launched in 2002, and the basic policies for urban renaissance were drawn up identifying the priority urban development areas for injecting extensive investment 'in order to implement the revitalisation of urban areas in a prioritised manner' [22]. In this way, responses to urban problems derived from the rapid changes in the socio-economic conditions (e.g. decline in birth rate and de-industrialisation) could be efficiently addressed since regeneration funding was planned to be concentrated on priority cities where population, industries and other activities had concentrated [23]. Additionally, use of Private Finance Initiatives (PFI) was proposed to encourage the private sector to lead urban regeneration projects in order to decrease the public sector's financial burden and to support the process of economic recovery from recession since the 1990s. These approaches appeared to be highly economy-driven and property-led regeneration, which seems to be a reflection of the Thatcher government's key strategies (e.g. Urban Development Corporations and PFI) in tackling urban decline and economic recessions during the 1980s.

The economic recovery was the key agenda for the Japanese government in the early 2000s. Although sustainability related issues such as negative effect of urban sprawl and traffic congestion in urban centres were briefly mentioned in the policies [22], sustainability agendas were not placed as the key player for urban renaissance in Japan. Brownfield or previously used land (PDL) would be considered to meet one of the designation standards for categorising the priority urban redevelopment areas - 'areas with heavy industries and others, which led the period of high economic growth, and have the potential for large-scale conversion in land usage' $[22,24]$. Hence, it is possible to argue that brownfield has a potential to be promoted as a development asset. However, in realty, brownfield has been viewed as a planning problem due to potential high remediation costs, complications in the development process and postremediation stigma. Despite the fact that the Soil Contamination Countermeasures Act 2003 (SCCA) offered some degree of financial support for undertaking investigations and suggested economical ways of managing contaminants (e.g. containment), policies for risk management of brownfield in general, do not seem to be well established. Furthermore, unlike in England, the shortage of housing is not a critical problem in Japan, and there has been lack of 
evidence to persuade developers to explore appropriate land uses on brownfield sites. Unless the Japanese government commits to the promotion of brownfield sites with a strong emphasis on urban renaissance agendas, it is almost impossible for brownfield to compete with 'clean' land and greenfield.

\section{Key drivers and barriers for brownfield regeneration}

The previous sections identified the contextual differences in understanding brownfield as a term and a political agenda between England and Japan. This section summarises key drivers and barriers for brownfield regeneration in the two countries (Table 1).

Table 1: $\quad$ Key drivers and barriers in England and Japan.

\begin{tabular}{|c|c|c|}
\hline & England & Japan \\
\hline$\stackrel{0}{0}$ & $\begin{array}{l}\text { - Government policies (sustainable } \\
\text { development and housing) } \\
\text { - Corporate Social Responsibility } \\
\text { - Strong lobbies for protecting greenfield } \\
\text { - A relatively buoyant property market }\end{array}$ & - Lack of drivers is the problem \\
\hline 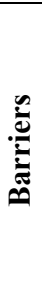 & $\begin{array}{l}\text { - Regional differences: more brownfield in } \\
\text { North-West England } \\
\text { - Physical constraints: complex } \\
\text { ownership, contamination, lack of } \\
\text { infrastructure } \\
\text { - Shortage of expertise (lack of skills) }\end{array}$ & $\begin{array}{l}\text { - Limited acceptance for remediation } \\
\text { methods: expensive 'dig and dump' is } \\
\text { the mainstream } \\
\text { - Stigma associated with brownfield: } \\
\text { difficulty in communicating risk } \\
\text { management to local communities } \\
\text { - Lower awareness of greenfield } \\
\text { protection. } \\
\text { - Recession for the last } 10 \text { years }\end{array}$ \\
\hline
\end{tabular}

\subsection{Key drivers}

In England, without doubt, the ultimate driver for brownfield regeneration is the government policies on creating sustainable communities and housing development on PDL. Research carried out by Dixon [18] suggested that the majority of developers in the UK have increased their output on brownfield over recent years and the main reasons for this were 'government policy' and 'availability of land'. This implies that the government policies worked effectively in bringing brownfield sites forward for smooth development. Furthermore, a relatively buoyant property market encouraged developers to view brownfield regeneration as an 'opportunity for profitable development' [18]. In addition to the government policies, Corporate Social Responsibility (CSR) appeared to be another driver for developers. In the rise of sustainability agendas in the UK, a number of investors and developers started launching their own environmental policies to demonstrate their commitment to addressing the development impacts on environment and society. Finally, it should be stressed that there have been strong lobbies for protecting greenfield. Traditionally the containment of urban expansion has been always in place [25], which acted as a 
strong driver for the reuse of brownfield. There has been a clear correlation between the government interest in brownfield redevelopment and the extent of public and political concern about environmental protection of the countryside [3]. For example, such environmental groups as Campaign to Protect Rural England (CPRE) [26] have a powerful influence on the evolution of national planning policies, which further pushed developers to turn to brownfield sites.

In contrast to those key drivers in England, there is lack of incentives for brownfield regeneration in Japan. Not only does the government not have comprehensive policies on brownfield, but also Japan seems to be short of other rationales to demonstrate immediate benefits of reusing PDL. Neither CSR nor protection for greenfields has been at the front line of debate over the future urban environment in Japan. Severe economic recession since the 1990s has been another cause for not exploring opportunities in the regeneration of difficult sites such as brownfield.

\subsection{Key barriers}

In England, a full body of literature exists discussing various constraints on bringing brownfield forward to beneficial use. Three main points are summarised here. Firstly, regional differences between north and south raise serious planning issues in England. Brownfield is disproportionately concentrated in northern regions where property markets are traditionally weak, whereas there is a lack of readily available brownfield sites in southern regions where shortage of new houses are critical [3]. The second element consists of physical constraints including complexity in land ownership, and time and cost implications for the remediation and lack of infrastructure. The third factor is shortage of appropriate professionals who will champion stakeholders of a brownfield project $[3,20]$. Nevertheless, although brownfield regeneration is still perceived as adding complexity, over 10 years of experience have brought some degree of confidence for stakeholders in England.

On the other hand, in Japan, there are a number of obstacles in the process of brownfield regeneration. Firstly, due to fear of health risks associated with contamination, only 'dig and dump' has been widely accepted for the redevelopment of brownfield. The SCCA applied a multifunctional approach for decontamination to contaminated land, thus standards for remediation were set to satisfy all types of end uses. Unlike England, Japan is bound to a limited number of remediation methods, which are comparatively expensive and environmentally unfriendly. Furthermore, stigma associated with brownfield seems to be much more significant than in England. According to a questionnaire survey of 9,000 medium-large enterprises (response rate $41 \%$ ), 65\% of the respondents answered that they would not purchase the real estate if there were a history of contamination [9]. Developers and end-users both are unwilling to get involved in brownfield development. Finally, Japan's lower awareness of rural protection should be noted. Historically, urban sprawl happened without much planning control and effectively there are not many voluntary or charity organisations to protect rural sites from greenfield development. 


\section{Conclusions}

This paper revealed the fundamental differences between England and Japan in understanding the term 'brownfield', in the government policy frameworks, and in incentives and obstacles for promoting the regeneration of brownfield.

The paper identifies a number of barriers for promoting brownfield regeneration in Japan. It may be practical for the Japanese government to learn from the UK government strategies that successfully reversed negative associations of brownfield by promoting it as a development asset by reforming planning policies. It is also not surprising to see a number of recent visitors from the public sectors in Japan to study English approaches to brownfield regeneration. Although there is urgent need for the Japanese government to establish a mechanism for re-branding brownfield as a development opportunity, there is a question to be addressed in advance - to what extent are the English approaches adaptable to the Japanese context? The present paper attempts to explore the possibilities of adaptability by discussing the contextual differences and commonalities between the two countries based on secondary sources and a series of discussions carried out by two English and Japanese academic institutions (Oxford Brookes and Osaka Universities). Yet, further research is required to answer the question including primary investigations.

For international comparison it is important to look at not only physical differences, but also at the cultural motivations and institutional frameworks of each county [3]. In our personal observation, Japanese people seem to be vulnerable to risks from health hazard caused by artificial disasters while they are comparatively resilient to natural disaster such as earthquakes. This kind of hypothesis can only be verified by using research methodologies based on not only the field of built environment, but also social anthropology. Brownfield is a subject that requires a wider range of knowledge integrated from various disciplines. In the UK and European contexts, multidisciplinary research consortia on brownfield issues such as SUBR: IM [27] and RESCUE [28] have been established. In Japan, there is a need to extend brownfield issues from narrowly defined environmental investigation (i.e. risk aversion and remediation) to wider socio-economic research agendas. As a final remark, it should be emphasised that there may be potential for English developers and consultancies to explore their business opportunities in Japan since brownfield regeneration is a relatively new and emerging policy agenda in Japan.

\section{Acknowledgement}

This paper is based on a research project that is funded by the Daiwa AngloJapanese Foundation and the Great Britain Sasakawa Foundation in the UK.

\section{References}

[1] Kurose, T. \& Murayama, A., Strategy for brownfield redevelopment on local cities in the US. Case studies of cities in New England. Summaries of technical papers of Annual Meeting Architectural Institute of Japan. F-1, 
Urban planning, building economics and housing problems, Vol.2006 (20060731), pp. 223-224, 2006.

[2] Miyagawa, T. \& Nakayama, T., Comparison of national acts on treating land contamination in Japan, The Netherlands, Germany, and the UK: Study on approaches to treat land contamination and redevelopment of brownfields Part 1, Journal of architecture, planning and environmental engineering. Transactions of Architectural Institute of Japan, No.547, p.177-183, 2001.

[3] Adams, D. \& De Sousa, C., Brownfield Development: A Comparison of North American and British Approaches. European Urban Research Association Conf. 'The Vital City', University of Glasgow, 12-14 September 2007.

[4] Dixon, T., Pocock, Y. \& Water, M. An analysis of the UK development industry's role in brownfield regeneration. Journal of Property Investment and Finance, 24(6), pp. 521-541, 2006.

[5] Alker, S., Joy, V., Roberts, P. \& Smith, N., The definition of brownfield. Journal of Environmental Planning and Management, 43(1), pp. 49-69. 2000.

[6] Raco, M. and Henderson, S., Sustainable urban planning and the brownfield development process in the United Kingdom: Lessons from the Thames Gateway. Local Environment, 11(5), pp. 499-513, 2006.

[7] Ganser, R. \& Williams, K., Brownfield Development: Are We Using the Right Targets? Evidence from England and Germany. European Planning Studies, 15(5), pp. 603-622, 2007.

[8] Department for Communities and Local Government (DCLG), Planning Policy Statement 3 (PPS3): Housing, HMSO: London, 2006.

[9] Ministry of Environment (MoE), Current status of the Brownfield Issue in Japan, Interim Report, MoE: Japan, 2007. http://www.env.go.jp/en/water/ soil/brownfields/interin-rep0703.pdf

[10] Yasutaka, T., Qualification of economical and social effects from the soil contamination and its solution, unpublished $\mathrm{PhD}$ thesis, Yokohama National University: Japan, 2007.

[11] Thornton, G. \& Nathanail, P., Are incentives for regenerating UK brownfield sites sustainable? Land Contamination \& Reclamation, 13 (4), pp.327-338, 2005.

[12] Imrie, R. \& Raco, M., Urban Renaissance? The Policy Press: Bristol, 2003.

[13] Department of Environment, Transport and Regions (DETR), Our Towns and Cities - the Future: Delivering an Urban Renaissance. London, The Stationery Office, 2000.

[14] Urban Task Force, Towards an Urban Renaissance, E\&FN Spon: London, 1999.

[15] Office for Deputy Prime Minister (ODPM), Planning Policy Statement 1: Delivering Sustainable Development, HMSO: London, 2005.

[16] Dair, C. and Williams, K., Sustainable land reuse: the influence of different stakeholders in achieving sustainable brownfield developments in England. Environment and Planning A, 38, pp. 1345-1366, 2006. 
[17] Raco, M., Henderson S. \& Bowlby, S., Delivering Brownfield Regeneration: Sustainable Community-Building in London and Manchester (Chapter 6). Sustainable Brownfield Regeneration, ed. T. Dixon et al, Blackwell Publishing, Oxford, pp. 119-139, 2007.

[18] Dixon, T., Integrating sustainability into brownfield regeneration: rhetoric or reality? An analysis of the UK development industry. Journal of Property Research, 23(3), pp. 249-279, 2006.

[19] Dixon, T. \& Adams, D., Housing Supply and Brownfield Regeneration in a post-Barker World: Is There Enough Brownfield Land in England and Scotland? Urban Studies, 45 (1), pp. 115-139, 2008.

[20] English Partnerships, Brownfield Strategy, Policy Consultation Workshop, Discussion paper: Policy issues and outline proposals, English Partnerships: London, UK, 2006.

[21] DCLG, Homes for the future: more affordable, more sustainable, The Stationery Office: London, 2007.

[22] Prime Minster of Japan and His Cabinet, Basic Policies for Urban Renaissance, 19 July, 2002, http://www.kantei.go.jp/foreign/policy/tosi/ kettei/020719kihon_e.html

[23] Izumi, H. Urban Renaissance in Japan, Urban Renaissance in Japan. Paper presented at Seminar on Urban Renaissance in the UK and Japan, The Daiwa Anglo-Japan Foundation: London, 22 September 2004.

[24] Kenmochi, I. \& Yamagata, S., Issues of urban regeneration and land valuation for contaminated land, 2003,http:/www.earth-app.co.jp/files/ 200310AcademicConference.pdf

[25] Ward, S. V., Planning and Urban Change, 2nd Edition, Paul Chapman Publishing: London, 2004.

[26] CPRE (Campaign to Protect Rural England), http://www.cpre.org.uk

[27] SUBR:IM (Sustainable Urban Brownfield Regeneration: Integrated Management), http://www.subrim.org.uk/

[28] RESCUE (Regeneration of European Sites in Cities and Urban Environments), http://www.rescue-europe.com/html/project.html 